\title{
Correction to: Exploring expected and perceived facilitators and barriers of an indicated prevention strategy to prevent future longterm sickness absence; a qualitative study among employers and employees
}

Sophie H. Klasen ${ }^{1 *}$, Ludovic G. P. M. van Amelsvoort ${ }^{1}$, Inge Houkes ${ }^{2}$, Nicole W. H. Jansen ${ }^{1}$ and IJmert Kant ${ }^{1}$

\section{Correction to: BMC Public Health (2021) 21:289 https://doi.org/10.1186/s12889-021-10322-w}

It was highlighted that in the original article [1] the numbers assigned to each image depicted in Fig. 1 were miss-numbered in the published version as 2-3-1 instead of 1-2-3. This Correction article shows the correct Fig. 1. The original article has been updated.

\section{Author details}

'Department of Epidemiology, Faculty of Health, Medicine and Life Sciences, CAPHRI School for Public Health and Primary Care, Maastricht University, P.O. Box 616, 6200, MD Maastricht, The Netherlands. ${ }^{2}$ Department of Social Medicine, Faculty of Health, Medicine and Life Sciences, CAPHRI School for Public Health and Primary Care, Maastricht University, Maastricht, The Netherlands.

Published online: 18 February 2021

\section{Reference}

1. Klasen SH, et al. Exploring expected and perceived facilitators and barriers of an indicated prevention strategy to prevent future longterm sickness absence; a qualitative study among employers and employees. BMC Public Health. 2021;21:289. https://doi.org/10.1186/s12889-021-10322-w.

The original article can be found online at https://doi.org/10.1186/s12889 021-10322-w.

* Correspondence: sophie.klasen@maastrichtuniversity.nl

'Department of Epidemiology, Faculty of Health, Medicine and Life Sciences, CAPHRI School for Public Health and Primary Care, Maastricht University, P.O. Box 616, 6200, MD Maastricht, The Netherlands

Full list of author information is available at the end of the article

(c) The Author(s). 2021 Open Access This article is licensed under a Creative Commons Attribution 4.0 International License, which permits use, sharing, adaptation, distribution and reproduction in any medium or format, as long as you give appropriate credit to the original author(s) and the source, provide a link to the Creative Commons licence, and indicate if changes were made. The images or other third party material in this article are included in the article's Creative Commons licence, unless indicated otherwise in a credit line to the material. If material is not included in the article's Creative Commons licence and your intended use is not permitted by statutory regulation or exceeds the permitted use, you will need to obtain permission directly from the copyright holder. To view a copy of this licence, visit http://creativecommons.org/licenses/by/4.0/. The Creative Commons Public Domain Dedication waiver (http://creativecommons.org/publicdomain/zero/1.0/) applies to the data made available in this article, unless otherwise stated in a credit line to the data. 
Klasen et al. BMC Public Health

(2021) 21:382

Page 2 of 2

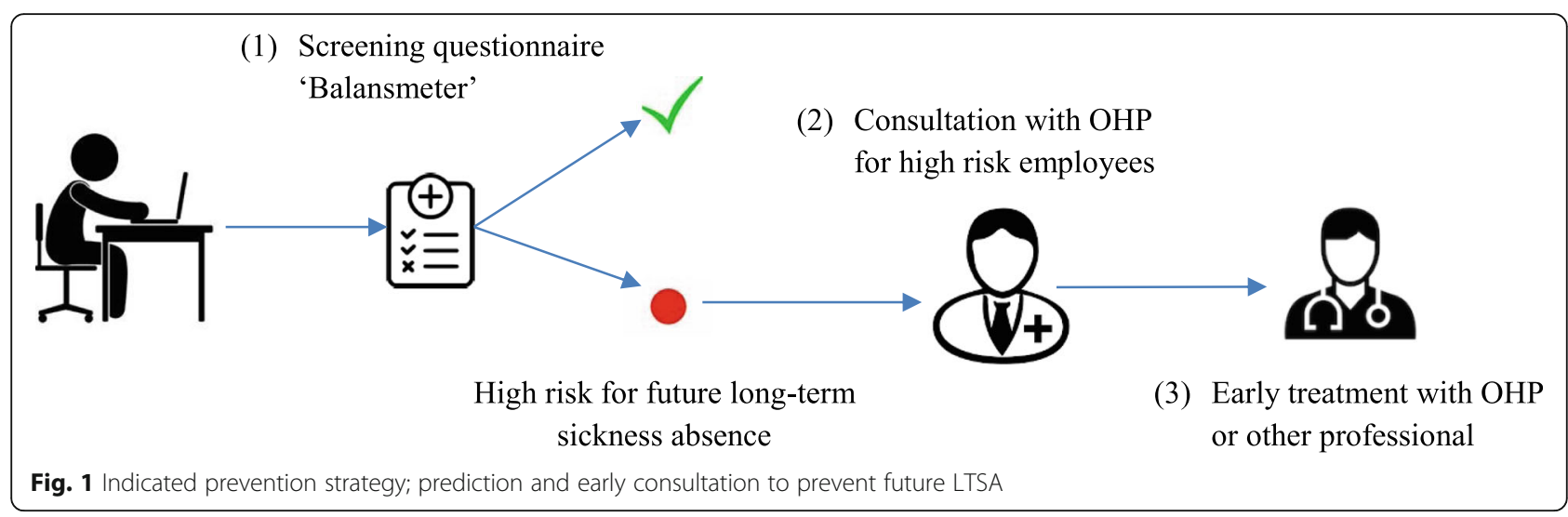

